\title{
A ÉTICA E A VIDA COTIDIANA NO TEMPO PRESENTE
}

José Geraldo Pedrosa. Doutor em Educação: História, Política, Sociedade. Docente do Programa de Pós-graduação em Educação Tecnológica do CEFET-MG, Brasil. E-mail: jgpedrosa@uol.com.br

A ética é uma invenção do Ocidente e surge na Polis ateniense entre 500 e 400 anos a.C. num momento de lucidez na existência humana, a despeito de todo machismo e escravismo. A polis ateniense da época de Sócrates elabora quatro referenciais do ocidente: a filosofia, a ética, a educação e a política. A ética é o ideal de fundação de uma comunidade orientada pela razão, como alternativa às comunidades fundadas na tradição, nos costumes ou na religião. Uma comunidade ética seria uma comunidade ancorada na razão e na liberdade, voltada para o bem comum, para a justiça e para a felicidade individual ${ }^{(1)}$.

A palavra ética é de origem grega, mas há controvérsias sobre duas possíveis origens etimológicas. Ética vem de ethos, que pode significar costume ou propriedade do caráter. O primeiro significado é que serviu de base para a tradução latina moral. No latim, o termo grego éthicos, foi traduzido por moralis. Por isso, há confusão entre ética e moral no uso vulgar da palavra.

A despeito dessa aparente similitude, há diferenças ontológicas entre ética e moral. Rebuscar essa diferença é importante no tempo presente: há uma onda de defesa da moral, da honra e dos costumes patriarcais. Na realidade, um álibi para conter a onda iniciada em 1968 e fazer regredir a afirmação da diversidade humana e das liberdades individuais. A moral é inimiga da liberdade e da diversidade.

O ideal de uma comunidade ética está associado à existência do sujeito individual e de sua autoconsciência: autonomia, autocontrole, autogoverno. Na comunidade ética, até as leis e o Estado seriam dispensáveis. Com ética, não há necessidade de governos sobre o homo: cada qual governa a si próprio, com razão e liberdade, visando à felicidade individual e ao bem comum.

Pois bem, esse era o ideal que se perdeu na modernidade industrial. A sociedade industrial é totalitária. É exigência da razão industrial que tudo se industrialize: a cultura, a educação, a vida. No tempo presente a vida tornou-se apêndice de uma gigantesca maquinaria industrial voltada para a produção de inutilidades letais. A síntese muda foi feita em 1936 por Chaplin, em "Tempos Modernos".

O primeiro atropelamento feito pela sociedade regida pela lógica da produção e do consumo visando ao lucro foi sobre a moral, que declinou no século XIX com a primeira e segunda ondas de expansão da indústria e do urbano. Disso não sabem os moralistas. A decadência da moral e sua capacidade de frear os impulsos humanos foi o desespero dos pensadores positivistas do século XIX, que fundaram a sociologia. Para os neuróticos da ordem, a decadência da moral trazia em si a probabilidade da desordem, ou disso que recentemente foi chamado de balbúrdia. 
Se o século XIX viu com a decadência da moral, o final do século XX, assistiu a corrosão do caráter. Essa é a tese do norte americano Richard Sennett. O que corrói o caráter é a prevalência do curto prazo na sociedade das efemeridades ${ }^{(2)}$. Caráter se fundamenta em valores e valores dependem da longa duração. Ademais, o caráter individual costuma ser um empecilho aos processos de adaptação e está longe de ser um atributo valorizado pelas empresas. Quanto mais caráter menor é a propensão do indivíduo se anular em função de interesses alheios.

No tempo presente, determinados imperativos invadem a vida cotidiana e deterioram a ética, tornando a vida em comum estressante, hostil e comumente insuportável ou somente suportável com o uso crescente e massificado das drogas lícitas e ilícitas: drogas em escala industrial.

Um imperativo da indústria que rege a vida cotidiana é o utilitarismo, cujo inventor é o inglês Jeremy Bentham, que também criou no século XVIII o modelo panóptico ${ }^{(3)}$. Regra básica do utilitarismo para separar o útil do inútil é a relação entre custos e benefícios. Vem daí a separação entre dias úteis e inúteis. Como utilitarismo muitos benefícios foram excluídos: a estética tornou-se inútil. Além disso, muitos custos nunca são contabilizados adequadamente como estratégia de viabilizar o consumismo: entre eles a natureza e o trabalho.

Outro imperativo da indústria que invade a vida cotidiana é o instrumentalismo, identificado pelo alemão Max Weber, no início do século XX. Na razão instrumental prevalecem os fins sobre os meios. Na era do planejamento instrumental e da calculabilidade, a lógica dos fins sacrifica o afeto e os valores ${ }^{(4)}$.

Outro imperativo da indústria que coage a vida cotidiana é a lógica mercantil; isso que coloca o mercado no centro da vida social. Mercado é lugar de competição e de lucro e a vida assim também se torna. Nos termos do imperativo mercantil, o lucro é o princípio de validação do útil: útil é o que dá lucro. Meio ambiente, nessa razão, só tem valor se dá lucro. A mercantilização da vida foi sintetizada na famosa frase de Benjamin Franklin: time is money ${ }^{(4)}$.

Por fim, o mais recente imperativo da era industrial que assalta a vida cotidiana é a norma estatal. 0 Estado, que surge como um meio, torna-se um fim em si mesmo. É o mito do equilíbrio: parece que se o orçamento estiver equilibrado, a vida toda se equilibrará e o mundo será feliz. É o mais recente dos fetiches: o do Estado. Agora é a sociedade que deve se sacrificar para o bem do Estado: sacrifício da aposentadoria dos velhos trabalhadores, da escola, da saúde, da ciência e da pesquisa públicas.

A prevalência do utilitarismo, do instrumentalismo, do mercantilismo e do fetiche do Estado na vida cotidiana, faz com que a vida se torne cada vez mais heteronômica. A vida torna-se meio de vida. E todos sabem: a vida como um fim é qualitativamente diferente da vida como um meio. Quando a vida é reduzida a um meio e quando a felicidade torna-se descartável é porque a ética foi sacrificada e reduzida a códigos e protocolos de controle de detalhes operacionais. Uma vida sem ética é uma vida danificada, prejudicada, à deriva e sem ideais humanos.

Temos que recuperar a ética e seu ideal de uma comunidade do bem comum. Para tal, é necessário reeducar o homo, antes que seja tarde demais. Para recuperarmos a ética é fundamental reconhecermos 
que ela se perdeu. Não há urgência maior no tempo presente do que a educação e, na educação, nada é mais relevante do que recuperar o ideal de uma comunidade ética.

\section{REFERÊNCIAS}

1. Jaeger W. A formação do homem grego. São Paulo: Martins Fontes; 1995.

2. Sennett R. A corrosão do caráter: Consequências pessoais do trabalho no novo capitalismo. São Paulo: Record; 2001.

3. Silva TT. O Panóptico/Jeremy Bentham. Belo Horizonte: Autêntica; 2005.

4. Weber M. A ética protestante e o espírito do capitalismo. São Paulo: Pioneira; 1992.

\section{Como citar este artigo:}

Pedrosa JG. A ética e a vida cotidiana no tempo presente. Revista de Enfermagem do Centro Oeste Mineiro. 2020;10: e4143. [Access___] Available in:__. DOI: 